\title{
Why protect civil liberties during a pandemic?
}

\author{
Peter Levine ${ }^{1}$ (iD
}

Accepted: 13 October 2020 / Published online: 18 January 2021

๑) Springer Nature Limited 2021

\begin{abstract}
During a public health emergency, a government must balance public welfare, equity, individual rights, and democratic processes and norms. These goods may conflict. Although science has a role in informing wise policy, no empirical evidence or algorithm can determine how to balance competing goods under conditions of uncertainty. Especially in a crisis, it is crucial to have a broad and free conversation about public policy. Many countries are moving in the opposite direction. Sixtyone percent of governments have imposed at least some problematic restrictions on individual rights or democratic processes during the COVID-19 pandemic, and 17 have made substantial negative changes. The policies of Poland and Hungary reflect these global trends and continue these countries' recent histories of democratic erosion. The expertise of public health should be deployed in defense of civil liberties.
\end{abstract}

Keywords Civil liberties · Republicanism · Democracy · COVID-19

Orzechowski et al. [1] provide a timely report on the erosion of civil liberties in Poland and Hungary during the COVID-19 pandemic. They conclude, "It should be the moral obligation of politicians, medical professionals but also the public to guarantee that the current pandemic will not be misused for political goals." I will support their argument by situating it in a somewhat broader theoretical and global context.

Imagine a government that is legitimate (having an unquestioned right to make laws and regulations within its territory) and benignly motivated. A pandemic such as COVID-19 will force this government to make difficult decisions. It should strive to maximize public welfare, which can be measured on the dimensions of health, economic prosperity, security, and environmental sustainability, among others. The government should strive for equity, meaning that the costs and harms (as well as any benefits) are distributed fairly. It should attend to individual rights, which can be understood as "trumps" that people may play against policies that benefit the

Peter Levine

peter.levine@tufts.edu

1 Tisch College of Civic Life, Tufts University, Medford, MA, USA

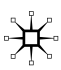


general welfare [2]. For example, an individual may claim a right to move freely when subjected to a quarantine; that claim presents a tradeoff that the government must resolve. Finally, the government should protect political processes and norms, such as a free and vibrant debate and fair elections.

These goods may conflict. Closing businesses has health benefits but also economic costs and may restrain individual economic rights. Allowing a mass protest enhances democratic debate but can allow a virus to spread. The relevant goods are incommensurable - not measurable on a single scale. And governments must weigh and balance them under conditions of uncertainty, not knowing for sure whether closing businesses will help control the epidemic or whether allowing a protest will spread the infection.

Now imagine that a government is neither legitimate nor benign. Perhaps a dictator has seized power in a coup. He, too, will face difficult choices during a pandemic, but there is no reason to expect him to weigh the costs and goods in an impartial fashion. More likely, he will see the pandemic as an opportunity to consolidate power, eliminate threats, and profit economically.

The United Nations recognizes 193 member states that vary in their legitimacy, their priorities, their capacity to make effective policy, their circumstances prior to the pandemic, and the way COVID-19 has affected them so far. Reasonable people also disagree about how to assess governments; for instance, a given regime may appear benign to some but not to others. Not surprisingly, the 193 national-level governments have made diverse policy choices so far in the COVID-19 pandemic, some of which conflict with civil liberties. For example:

- the Slovak "military quarantined five Roma settlements that had not yet hit the requisite infection threshold established by the government";

- "at least a dozen journalists in Bangladesh are facing life sentences for publishing criticism of the government's response to the pandemic"; and

- legislatures in Eritrea, Ethiopia, and Zambia have been dissolved on account of the pandemic [3].

Orzechowski et al. [1] focus on Hungary and Poland. Hungary "passed a set of regulations that give the government a right to issue special decrees under emergency rule." The Polish Ministry of Health banned "consultants and epidemiologists from expressing their views on the virus or on [the] reaction of public health authorities to the pandemic." These acts can be seen as examples of a global trend. Sixty-one percent of countries have imposed at least some problematic restrictions on individual rights or democratic processes during the pandemic, and 17 countries have made substantial negative changes. Hungary ranks second-worst on a global list of countries that have restricted civil liberties during the pandemic [3].

Prior to the pandemic, Hungary and Poland had been widely accused of eroding liberal and democratic norms. Although that charge is contestable (and any regime has many features and attributes that reasonable people may assess differently), it is helpful to place these countries on a spectrum between liberty and domination. In the tradition of republican thought, "liberty" means that everyone is always owed an explanation; decision-makers are accountable for their actions and their reasons. 
"Domination" means that rulers may make decisions without having to give reasons for them. Republican liberty and domination are strict opposites [4, 5].

To measure liberty in the republican sense, we might select three illustrative factors:

- Organizations independent of the state must be free to operate and advocate as they wish, because that is the basis of a free public debate.

- Leaders must feel an obligation to give reasoned justification for their decisions.

- Laws must be transparent and predictably enforced so that individuals are governed by laws and not subject to the will of powerful people.

Varieties of Democracy (V-Dem) is an independent research institute based in the Department of Political Science at the University of Gothenburg, Sweden that assesses almost every country in the world [6]. V-Dem enlists a minimum of five experts on each country to evaluate those three factors (among many others) annually. Figures 1 and 2 show the experts' mean ratings for Hungary and Poland. All three measures improved rapidly in Hungary after the collapse of communism in 1989 but then plummeted since 2010, when Viktor Orbán became prime minister (Fig. 1). A similar pattern is evident in Poland, with the turning point being the election of Andrzej Duda as Poland's president in 2015 (Fig. 2). The graphs end in 2019, but the policies that these countries have adopted in 2020 should be understood in historical context. Prior to the pandemic, Hungary and Poland were not fully legitimate and benign democracies, although they were far from the most repressive states, and their political conditions were not identical. Freedom House, a US-based nonprofit founded in 1941 that issues a prominent annual report on the state of freedom in the world, rates Hungary as "partly free" with a score of 70 on a 1-100 scale, and Poland as "free" with a score of 84. By comparison, Sweden scores 100, and Turkmenistan scores 2 [7] Both Poland and (to a greater extent) Hungary illustrate a global trend toward the politics of domination. Freedom House asserts that 2019 was the 14th consecutive year in which freedom has declined globally [8].

Considering that making good policy in a pandemic means balancing incommensurable goods under conditions of uncertainty and limited control, how should governments decide? The authors of the Viewpoint about which I write say, "decisions should not be based on political strategy but on scientific data" [1]. Science certainly has a role, but no empirical evidence or algorithm can determine how to balance potentially competing goods, such as individual liberty versus public health, economic equity versus economic growth, or controlling the virus versus protesting the government.

We need a broader conversation than a merely scientific one. Germany set an interesting standard by including "philosophers, historians, theologians and jurists" among its official advisors [9]. That is still an elite approach, and it needs the complement of a public debate. Leaders must be compelled to give the public evidence and reasons for all their decisions; and a wide range of citizens must be free to criticize the state, defend various goods, and present alternative policies. Robust debate is more, not less, important during a crisis, when the potential for making dangerous errors is most severe. In a classic paper, Amartya Sen noted that no democracy has 


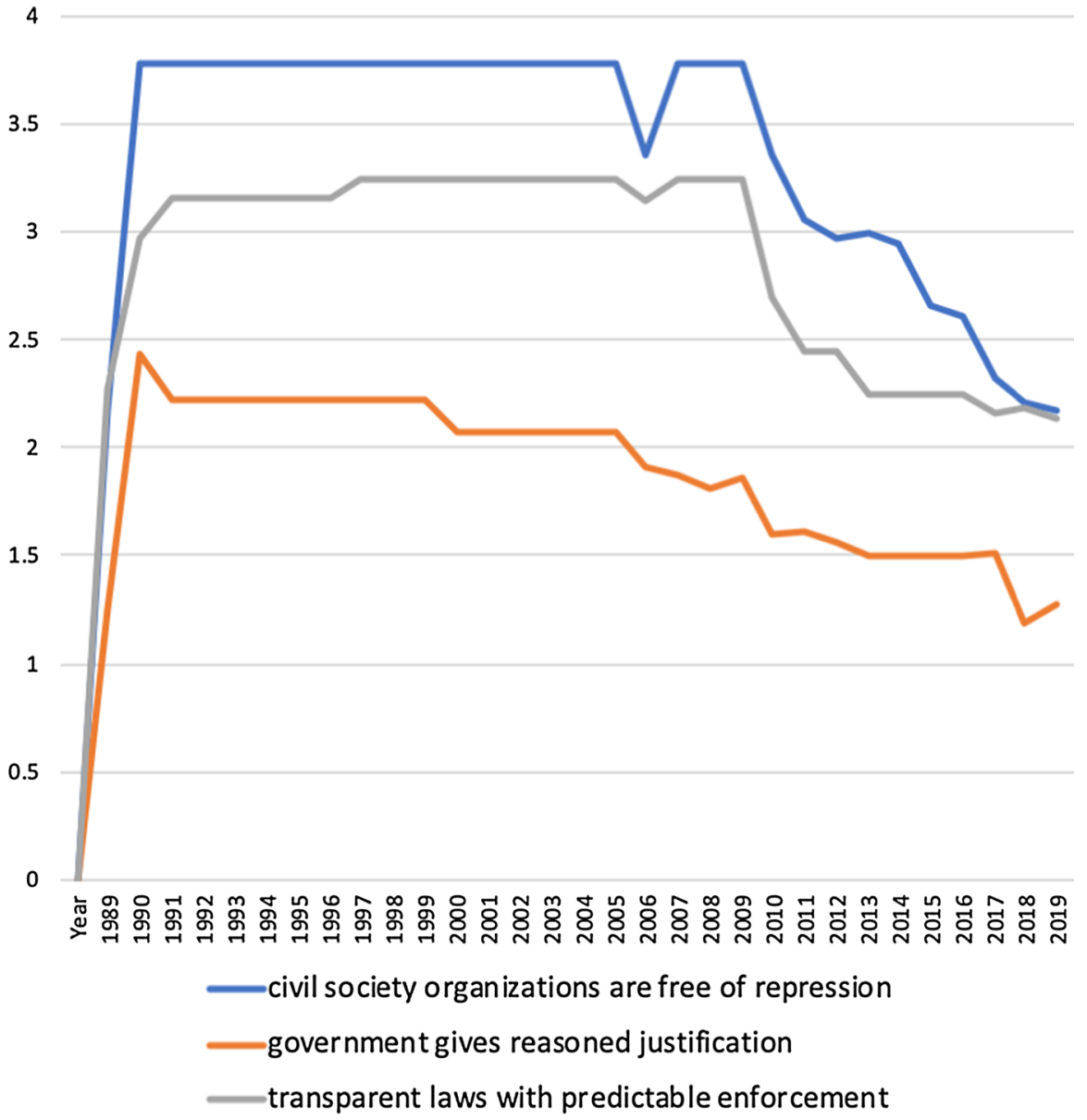

Fig. 1 The experts' mean ratings for Hungary

ever permitted a famine. Sen argued that the reasons included free flow of information during a food crisis, reliable data about what is happening on the ground, and accountability [10]. The same arguments would apply in a health crisis such as a pandemic.

To be sure, there can be tradeoffs between democratic participation and public health. A mass protest, a face-to-face public legislative meeting, or an election can present opportunities for an infection to spread. Governments may argue for delaying such activities. Nevertheless, public health experts and authorities should lean strongly in favor of protecting civil liberties because of their role in good governance, which is especially important in a crisis.

Marc Lipsitch, a Harvard professor of epidemiology, offered his professional opinion about the recent anti-racism protests in the United States. Lipsitch acknowledged that there may have been COVID-19 transmissions during these protests, and he urged 
4.5

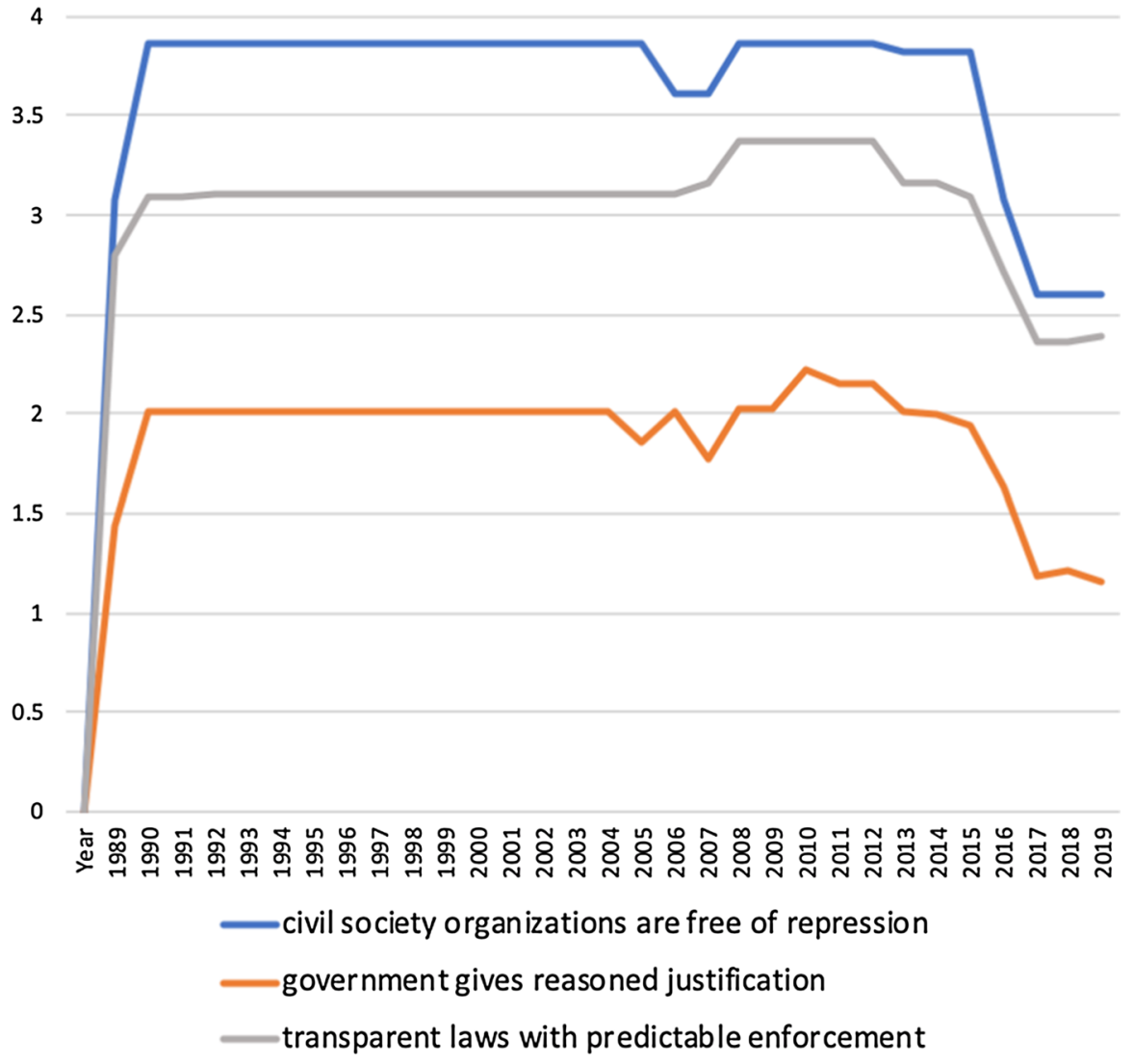

Fig. 2 The experts' mean ratings for Poland

the protesters to take "as many precautions as possible." At the same time, he argued that mass protests should only be banned if all other outdoor gatherings were also prohibited, and he defended the particular importance of civil liberties. "On the continuum between buying food, which we have to do to live, and many of the other things that states around the country are not just permitting but encouraging, I would say protesting racial injustice is closer to something that people need to do to live, at least, for others to live" [11]. Here Lipsitch demonstrated how to put the expertise of public health on the side of civil liberties, which is where it belongs. 


\section{References}

1. Orzechowski M, Schochow M, Steger F. Balancing public health and civil liberties in times of pandemic. J Public Health Policy. 2021. https://doi.org/10.1057/s41271-020-00261-y.

2. Dworkin R. Rights as trumps. In: Kavanagh E, Oberdiek J, editors. Arguing about law. Abingdon: Routledge; 2013. p. 335-44.

3. Edgall A, Grahn S, Lachapelle J, Lührmann A, Maerz S. An update on pandemic backsliding: democracy four months after the beginning of the Covid-19 pandemic. V-dem Policy Brief. 2020 No. \#24, $30 \mathrm{~J}$.

4. Pettit P. Republicanism: a theory of freedom and government. Oxford: Clarendon Press; 1997.

5. Shapiro I. Politics against domination. Cambridge: Harvard University Press; 2016.

6. Coppedge M, Gerring J, Knutsen CH, Lindberg SI, Teorell J, Altman D, Bernhard M, Fish MS, Glynn A, Hicken A, Luhrmann A, Marquardt KL, McMann K, Paxton P, Pemstein D, Seim B, Sigman R, Skaaning S-E, Staton J, Wilson S, Cornell A, Alizada N, Gastaldi L, Gjerløw H, Hindle G, Ilchenko N, Maxwell L, Mechkova V, Medzihorsky J, von Römer J, Sundström A, Tzelgov E, Wang Y, Wig T, Ziblatt D. V-Dem [Country-Year/Country-Date] Dataset v10. Varieties of Democracy (V-Dem) Project. https://doi.org/10.23696/vdemds20.

7. Freedom House. Countries and territories [Internet]. C2020. https://freedomhouse.org/countries/ freedom-world/scores2020.

8. Repucci S. Freedom in the world 2020: a leaderless struggle for democracy. [Internet] Freedom House. 2020. https://freedomhouse.org/report/freedom-world/2020/leaderless-struggle-democracy.

9. Matthers D. Germany enlists humanities scholars to end coronavirus lockdown. Times Higher Education [Internet] 2020, April 26. https://www.weforum.org/agenda/2020/04/german-humanities -scholars-enlisted-to-end-coronavirus-lockdown/.

10. Sen A. Development: which way now? Econ J. 1983;93(372):745-62.

11. Chotiner I. What activities are safe as the coronavirus continues to spread? [Internet] New Yorker. 2020, June 27. https://www.newyorker.com/news/q-and-a/what-activities-are-safe-as-the-coronaviru s-continues-to-spread.

Publisher's Note Springer Nature remains neutral with regard to jurisdictional claims in published maps and institutional affiliations.

Peter Levine is Lincoln Filene Professor in the Tisch College of Civic Life, Tufts University, Medford, MA, USA. 